\begin{tabular}{|lcc|}
\hline & TOTOBUANG & \\
\hline Volume 9 & Nomor 1, Juni 2021 & Halaman 117-129 \\
\hline
\end{tabular}

\title{
EKSKLUSI PEREMPUAN, SASTRA, DAN PSIKOLOGI GENDER: STUDI PADA CERPEN KARYA BUDI DARMA TAHUN 2016--2020 (Female Exclusion, Literature, and Gender Psychology: Study On Budi Darma's Short Stories 2016--2020)
}

\author{
Anas Ahmadi \\ Bahasa dan Sastra Indonesia, Universitas Negeri Surabaya \\ Lidah Wetan, Surabaya, Indonesia \\ Pos-el: anasahmadi@ unesa.ac.id
}

Diterima: 20 Januari 2021; Direvisi: 25 Mei 2021; Disetujui: 27 Mei 2021

doi: https://doi.org/10.26499/ttbng.v9i1.290

\begin{abstract}
The study of gender is currently attracting the researchers from various fields. One of them is research gender in literature. Therefore, this study aims to describe the exclusion of women contained in Indonesian literature through a gender psychology perspective. The method used qualitative with narrative exposure style. The data source used a short story by Budi Darma in 2016-2020. Data analysis techniques includes identification, classification, and data exposure. The results of the study and discussion showed that exclusion in literature emerged some categories: (1) exclusion of women through the selection of short story titles that were more tendent to men, (2) exclusion of wartime women, and (3) exclusion of women through labeling.

Keywords: exclusion, literature, labelling, psychology, gender psychology
\end{abstract}

\begin{abstract}
Abstrak
Studi mengenai gender saat ini menarik perhatian peneliti berbagai bidang. Salah satunya adalah penelitian gender di bidang sastra. Berkait dengan itu, penelitian ini bertujuan untuk mendeskripsikan eksklusi perempuan yang terdapat dalam sastra Indonesia melalui perspektif psikologi gender. Metode yang digunakan adalah kualitatif dengan gaya pemaparan naratif. Sumber data yang digunakan adalah cerpen karya Budi Darma tahun 2016-2020. Teknik analisis data meliputi, identifikasi, klasifikasi, dan pemaparan data. Hasil penelitian dan pembahasan menunjukkan bahwa eksklusi dalam literatur muncul dengan kategori (1) eksklusi perempuan melalui pemilihan judul cerpen yang lebih condong kepada laki-laki, (2) eksklusi perempuan masa perang, dan (3) eksklusi perempuan. melalui pelabelan.
\end{abstract}

Kata-kata kunci: eksklusi, sastra, labelling, psikologi, psikologi gender

\section{PENDAHULUAN}

Studi tentang perempuan saat ini sudah banyak dilakukan oleh peneliti, baik melalui perspektif pria ataupun perspektif perempuan itu sendiri. Keduanya, memiliki koridor kritis dalam memahami dan menginterpretasi perempuan. Dalam konteks gender, studi perempuan sudah digali melalui perspektif perempuan sebagai istri dan janda (Lanza, 2007; Conger, 2009; Reeder, 2003), perempuan migran (Briones,
2009), perempuan dan politik (Jeydel, 2004), perempuan dan sastra (Warren, 2005; Orabueze, 2015), perempuan dan keadilan/ketidakadilan (Gregory, 2003). Studi perempuan perspektif gender tersebut menunjukkan bahwa perempuan mulai dari dulu sampai sekarang mengalami dinamisasi dalam hal konsep, teori, dan metodologi yang berkait dengan studi perempuan. Dinamisasi dalam studi perempuan dan studi gender itulah yang menarik untuk dikaji 
secara mendalam, baik secara filosofis, psikologis, sosiologis, antropologis, ataupun religius.

Berkait dengan konteks studi mengenai perempuan yang ditinjau dari perspektif gender, memang sudah banyak sebagaimana dipaparkan pada bahasan di awal. Sebagaimana diketahui bersama, studi tentang perempuan dalam perspektif gender bisa ditinjau dari segi usia, seks, agama, perkawinan, pekerjaan, politik, sosial, budaya, filsafat, kriminologi, ketidakadilan, migran, dan pendidikan. Studi tersebut muncul dalam bentuk monodisipliner dan interdisipliner. Dalam bentuk monodisipliner, studi gender dikaitkan hanya dengan satu studi saya. Adapun studi interdisipliner dikaitkan dengan dua atau lebih studi yang digunakan.

Berkait dengan gender, Ridgeway (2011) menunjukkan bahwa manusia modern saat ini, jika ditinjau dari perspektif gender, memang masih kuat dalam 'inequality'. Hal tersebut terjadi pada negara-negara besar yang sebenarnya cara berpikir masyarakatnya sudah terbuka, demokratis, dan berkeadilan. Apalagi, jika melihat gender yang berada di negara-negara yang cara berpikirnya masih tradisional dan masih banyak ditopang oleh pemikiran patriarkhal.

Fenomena yang 'inequality' di negara maju ataupun di negara berkembang saat ini sangat merugikan kaum perempuan sebab ketidakadilan gender akan menguntungkan satu pihak dan merugikan pihak yang lainnya. Dalam hal ini, pihak yang banyak diuntungkan adalah kaum laki-laki. Mereka sebagai kaum patriarkhal banyak menguasai negara dan membuat undang-undang yang memenangkan kaum laki-laki. Hal tersebut memang menjadi catatan Saadawi (2021) bahwa laki-laki menguasai perempuan melalui sistem yang dibuat oleh mereka. Dengan demikian, perempuan dibuat tidak berdaya dengan sistem yang sengaja dibuat oleh kaum laki-laki.
Studi tentang perempuan dalam kaitannya dengan ketidakadilan gender sudah pernah dilakukan oleh Jacobsen (2011) yang meneliti ketidakadilan gender dalam konteks pekerjaan skala global. Dia menunjukkan bahwa setiap tahun ketidakadilan gender di konteks perkerjaan terjadi. Sakariyau \& Zakuan (2017) yang meneliti ketidakadilan gender di Nigeria dan Malaysia dalam konteks politik. Hasil penelitiannya menunjukkan bahwa kedudukan perempuan dalam konteks politik di Nigeria dan di Malaysia masih rendah jika dibandingkan dengan kedudukan laki-laki dalam di kancah politik. Hal ini mengeksplisitkan bahwa ketidakadilan gender dalam hal politik di kedua negara tersebut masih tinggi. Kedua penelitian yang berkait dengan studi gender tersebut terdahulu tersebut belum menyentuh konteks eksklusi dengan menggunakan perspektif psikologi gender. Padahal, eksklusi perempuan dengan kacamata psikologi gender mampu memberikan terobosan baru dalam kaitannya dengan peminggiran perempuan melalui koridor psikologis. Selain itu, masyarakat bisa mendapatkan wacana baru bahwa studi gender juga bisa ditinjau dari perspektif psikologi.

Berkait dengan konteks gender, sastra sebagai karya kreatif juga memunculkan topik yang berkait dengan gender, marginalisasi, ataupun penindasan. Peneliti tersebut antara lain sebagai berikut. Corse \& Westervelt (2002) meneliti sastra yang dikaitkan dengan pembacaan dari perspektif perempuan. Hasil penelitiannya menunjukkan bahwa terjadi perubahan strategi interpretasi pada pembacaan novel yang dilakukan oleh perempuan pada era dulu dengan era modern. Perubahan tersebut disebabkan oleh kesadaran perempuan dalam hal pembacaan dan penginterpretasian teks. Selama ini, teks cenderung dibaca dan diinterpretasi secara objektif. Padahal, teks sebagai sebuah ideologi dikonstruksi secara subjektif oleh si pencipta. Karena itu, 
dibutuhkan pembacaan dan penginterpretasian yang mendalam agar bisa mendapatkan temuan yang kritis berkait dengan makna teks.

Page (2003) meneliti sastra perspektif perempuan dalam kaitannya dengan feminisme naratologi. Dalam konteks ini, Page menandaskan bahwa teks sastra harus dibaca secara mendalam melalui perspektif feminisme naratologi atas bisa menggali teks sastra secara tepat. Janssen \& Muracher (2005) meneliti tentang gender dalam sastra yang dikaitkan dengan konteks pembaca. Dia menunjukkan bahwa aspek jenis kelamin pengarang tidak bisa disembunyikan dari pembaca sebab hal tersebut tampak dalam karyanya.

Selain itu, penelitian yang dilakukan oleh Suman (2018) mengkaji masalah migrasi dan gender dalam konteks kesasraan. Hasil penelitiannya menunjukkan bahwa migrasi memiliki pengaruh terhadap tulisan para sastrawan dalam kiatannya dengan konteks gender. Penelitian yang dilakukan Suman tersebut menunjukkan bahwa gender dalam sastra juga bisa dikaji melalui perspektif migrasi. Adapun Ahmadi (2021) meneliti trauma perempuan konteks gender dalam sastra Indonesia yang difokuskan pada novel yang di dalamnya merepresentasikan tragedi 11 Mei. Hasil penelitiannya menunjukkan bahwa sastra Indonesia sebagai teks fiksi juga mengungkapkan kebenaran melalui sastra. Kebenaran yang kadang tidak diungkap dalam media massa sebab dianggap sebagai hal yang sensitif untuk dipublikasikan ke masyarakat.

Studi mengenai gender dalam sastra merupakan hal yang menarik sebab melalui sastra bisa ditemukan konstruksi eksklusi terhadap perempuan (Saadawi, 2015, 2021) yang selama ini ditutupi oleh kekuatan patriakhi. Sastra adalah 'suara lain' yang mampu menunjukkan ketidakadilan gender, eksklusi, dan penindasan terhadap kaum perempuan yang dilakukan oleh laki-laki.
Sastra adalah dunia realitas dalam fiksi yang sebenarnya di dalamnya memang benar-benar menggambarkan realitas lain yang kadang tidak diungkap dalam media massa. Hal tersebut disebabkan media massa yang bungkam dengan kondisi realitas 'inequality' sebab mereka sudah dibungkam oleh penguasa yang lebih banyak didominasi oleh kaum laki-laki.

Bertolak dari paparan tersebut dalam artikel ini bertujuan untuk mengungkap dan mengeksplorasi eksklusi perempuan dalam sastra Indonesia perspektif psikologi gender. Secara spefisik, artikel ini difokuskan pada cerpen karya Budi Darma yang ditulis pada tahun 2016-2020. Dipilihnya karya-karya Budi Darma sebagai sumber data penelitian sebab karya-karya yang ditulis oleh Budi Darma sangat kuat dalam menonjolkan aspek psikologis (Siswanto, 2005). Hal tersebut sangat kuat dalam pemunculan psike dan perilaku tokoh dalam karya yang ditulis oleh Budi Darma, baik dalam bentuk cerpen (Darma, 2002) ataupun novel (Darma, 1988, 1996, 2009) yang ditulisnya baik ketika di Amerika maupun di Indonesia. Tujuan penelitian ini adalah mendeskripsikan eksklusi perempuan dalam cerpen yang ditulis oleh Budi Darma rentang tahun 2016-2020. Manfaat penelitian ini diharapkan dapat memberikan kontribusi teoretis maupun praktis dalam khasanah kritik sastra yang berkait dengan psikologi sastra, khususnya psikologi gender.

\section{LANDASAN TEORI}

Dalam perspektif psikologi, studi psikologi gender memang bukan masuk dalam kategori arus utama. Psikologi arus utama ialah psikologi mainstream, misalnya psikoanalisis, behavioral, eksistensialisme, ataupun humanisme. Psikologi gender merupakan psikologi generasi baru yang merupakan kategori studi interdisipliner antara studi psikologi dan studi gender. Dalam pandangan tradisional, istilah gender sering dihampirsamakan dengan seks. 
Padahal, seks dan gender memiliki keberbedaan makna yang mendalam. Seks berkait dengan kodrati yang stagnan dan sulit diubah, sedangkan gender berkait dengan konstruksi budaya yang terdapat dalam masyarakat. Dengan demikian, seks dan gender memiliki keberbedaan yang besar dalam hal pemaknaan dan implementasi pemaknaan tersebut di masyarakat.

Sastra sebagai konkretisasi dari dunia pemikiran dan imajinasi sang pengarang tidak lepas pula dari konteks psikologi (Ahmadi, 2015). Begitu pula dengan sastra Indonesia, di dalamnya juga merepresentasikan dunia psikologi, baik psikologi pengarang, karya, dan pembaca. Studi sastra Indonesia, sebagaimana diketahui bersama, saat ini memang mengalami perkembangan yang pesat dan ditinjau dari berbagai studi (Ahmadi, dkk, 2019a; Ahmadi, 2019b; Ahmadi, 2019c). Studi itu menunjukkan bahwa sastra Indonesia memang sangat dinamis dalam hal kajian, mulai dari yang monodisipliner, interdisipliner, sampai dengan transdisipliner.

Studi yang saat ini menaik dalam ranah sastra, salah satu di antaranya studi gender. Ahmadi (2014, 2015, 2017) menunjukkan bahwa sastra memang tidak bisa lepas dari konteks relasi opresikooptasi, keadilan-ketidakadilan, dan maskulinitas-feminitas. Konteks tersebut merupakan wilayah studi gender. Melalui studi gender, sastra dianggap sebagai artefak kebudayaan yang di dalamnya secara sadar ataupun tidak sadar merepresentasikan pertarungan budaya yang dikonstruksi oleh pria ataupun perempuan. Selama ini, studi gender cenderung mengarah pada suatu kontruksi yang dibangun oleh laki-laki dalam menguatkan kekuasaannya. Hal inilah yang menjadi topik besar dalam studi gender. Meskipun demikian, tidak menutup kemungkinan bahwa laki-laki juga dikalahkan oleh perempuan dalam berbagai segmentasi kehidupan.
Psikologi gender sebagaimana yang dikonseptualisasi oleh Helgeson (2012), psikologi yang memfokuskan kajian pada representasi konstruksi sosio-budaya masyarakat yang memengaruhi pria dan perempuan. Dalam konteks ini, psikologi turut berperan serta sebab konstruksi psikologis individu juga muncul di masyarakat sebagai bentuk keterpengaruhan, relasional, ataupun timbal balik. Dengan demikian, perilaku dan proses mental individu turut dipengaruhi oleh konstruksi sosio-budaya masyarakat sehingga memunculkan adanya keseimbangan gender, ketidaksedimbangan gender, ataupun hubungan relasional dalam gender.

Psikologi gender dalam kaitannya dengan sastra difokuskan pada ide, narasi, ataupun perlakukan tokoh yang dimunculkan oleh sang pengarang, baik dalam bentuk monolog ataupun dialog. Selain itu, psikologi gender dalam sastra juga berkait dengan narasi sang pengarang sebagai kreator karya sastra. Dalam konteks psikologis, sang pengarang secara sadar ataupun tidak sadar memunculkan ketidaksetaraan gender dalam karyakaryanya.

\section{METODE}

Penelitian ini menggunakan jenis deskriptif kualitatif sebab peneliti lebih banyak menggunakan dan memaparkan data secara deskriptif. Dalam kaitannya dengan konteks pendekatan sastra, peneliti mengunakan pendekatan psikologi kualitatif, yakni studi psikologi sastra yang di dalamnya lebih banyak menggunakan data-data berupa verbal dan deskriptif deskripsi (Ahmadi, 2019a). Pendeskripsian tersebut merupakan hasil dari interpretasi kualitatif terhadap data yang digunakan oleh peneliti. Jika dikaitkan dengan konteks kesastraan, metode psikologi kualitatif lebih cenderung pada memaparkan data kesastraaan dengan menggunakan deskripsi, bukan pada angka. 
Gergen (2010:103) memberikan batasan bahwa metode dalam penelitian gender bisa berkait dengan studi naratif sebab peneliti menggunakan gaya paparan dalam analisis dan pembahasan. Berkait dengan hal tersebut, metode dalam penelitian ini lebih diarahkan pada naratif riset (Creswell \& Creswell, 2019) yang mengacu pada konteks interpretasi dan inquiri riset. Dalam kaitannya dengan studi gender yang menggunakan naratif, peneliti lebih banyak mengeksplorasi dan menginterpretasi data teks sastra (berupa cerita pendek) dengan bahasa yang natural dan reflektif. Dengan begitu, hasil analisis dan pembahasan yang dipapakan oleh peneliti lebih bersifat reflektif-interpretatif.

Berkait dengan studi psikologi gender, Helgeson (2012:38) menjustifikasi bahwa penelitian psikologi gender memiliki salah satu kesulitan yang unik, yakni bias gender. Seorang peneliti kadang terpengaruh secara emosional dalam memaparkan data yang berkait dengan hasil penelitian. Hal tersebut memang wajar dalam kaitannya dengan peran gender yang memang akan memengaruhi konstruksi pikir seseorang.

Untuk mengurangi kadar bias gender yang terjadi dalam proses penggalian data, proses penginterpretasian data, proses pengonstruksian data penelitian tersebut, peneliti melakukan tingulasi data, triangulasi teori, dan triangulasi metodologi.

Triangulasi data dilakukan oleh peneliti dengan cara pembacaan secara simultan sehingga bisa ditemukan kelemahan pada data. Triangulasi teori dilakukan oleh peneliti dengan cara melakukan pembacaan secara simultan berkait dengan teori dan penambahkan diskusi teori yang terbaru (relevan dengan psikologi gender) dengan harapan teori bisa lebih kokoh. Adapun tiangulasi metodologis dilakukan oleh peneliti dengan cara mendiskusikannya dengan praktisi sastra dan mendapatkan masukan dari teman sejawat berkait dengan metodologis. Dengan begitu, data, teori, dan metodologi diharapkan bisa lebih optimal dan meminimalisasi bias yang terdapat dalam penelitian. Melalui triangulasi tersebut diharapkan hasil paparan menjadi lebih ilmiah dan dapat dipertanggungjawabkan secara rasional.

Teknik pengumpulan data dalam penelitian ini mengacu pada studi sastra teks. Dengan begitu, peneliti menggunakan teknik dokumentatif dan kepustakaan yang memiliki relevansi dengan cerpen yang ditulis oleh Budi Darma rentang tahun 20162020. Secara spesifik, teknik dokumentatif tersebut dilakukan oleh peneliti dengan cara mencari, mengumpulkan, dan memilah cerpen karya Budi Darma yang tersebar di media massa, yakni Kompas dan Jawa Pos. Peneliti memilih media massa Kompas dan Jawa Pos sebab dalam skala nasional, kedua media massa tersebut memuat naskah sastra (genre cerpen) dan tulisan Budi Darma dimuat di media massa tersebut. Selain itu, Kompas dan Jawa Pos juga merupakan koran yang menjadi barometer nasional dalam kaitannya dengan konstelasi sastra di Indonesia.

Sumber data yang digunakan dalam penelitian ini berupa cerpen Indonesia yang ditulis oleh Budi Darma rentang 2016-2018 yang dimuat di Kompas dan Jawa Pos, yakni "Suara di Bandara (2018, Kompas), "Lorong Gelap (2018, Kompas), "Bukan Mahasiswa Saya" (2017, Jawa Pos), Tarom (2017, Kompas), "Tukang Cukur" (2016, Kompas), "Presiden Jebule" (2016, Kompas), "Darojat dan Istrinya" (2016, Jawa Pos), "Tamu" (2019, Kompas), "Prokol Bambu Martoyo" (Jawa Pos, 2020).

Data yang digunakan dalam penelitian berupa diksi, frasa, kalimat, dan struktur teks yang terdapat dalam cerpen karya Budi Darma yang ditulis dan diterbitkan rentang tahun 2016 sampai dengan 2020. Teknik analisis data yang dilakukan oleh peneliti menggunakan tahapan sebagai berikut (1) tahapan identifikasi data yang relevan dengan eksklusi perempuan dalam cerpen karya Budi Darma; (2) tahapan klasifikasi data yang relevan dengan eksklusi 
perempuan dalam cerpen karya Budi Darma, dan (3) pemaparan data.

\section{PEMBAHASAN}

\section{Eksklusi Perempuan dalam Konteks Pengunaan Judul Cerpen}

Konstruksi psikologis seorang pengarang akan memengaruhi cara menuangkan gagasan dalam karya sastranya. Sang pengarang dalam hal ini terkadang tidak sadar memunculkan konstruksikonstruksi psikologis dalam karyanya. Konstruksi psikologis tersebut bisa muncul dalam bentuk proyeksi, sublimasi, ataupun kondensasi.

Hal tersebut sejalan dengan pandangan psikologi Freudian (Freud, 1920) bahwa manusia lebih banyak didorong oleh pulsi ketidaksadaran individual. Munculnya ketidaksadaran individual tersebut didorong energi besar yang berada dalam alam bawah sadar manusia agar muncul ke permukaan dalam bentuk yang lain. Energi tersebut muncul dengan kuat sebab terdorong oleh id yang terdapat dalam diri manusia. Id dalam hal ini bersifat instinktif dan setiap individu memiliki. Id tersebutlah yang akan menggerakkan alam ketidaksadaran manusia.

Manusia yang memiliki id yang kuat, akan mengalahkan kekuatan struktur kepribadian yang lainnya,yakni ego dan supergego. Dalam hal ini, ego adalah penyembang antara id dan superego ketika keduanya bertentangan. Super ego dalam hal ini merupakan struktur kepribadian yang lebih banyak mengarah pada realitas kehidupan, etika, dan apa yang harus dilakukan manusia dalam kehidupan bermasyarakat. Jika id yang memang dalam pertarungan dengan ego dan superego, manusia akan lebih banyak dituntun oleh ketidaksadaran individual yang instinktif dan primitif. Ketidaksadaran ini lebih mengedepankan hasrat manusia yang kadang infantil, jahat, seks, dan kebinatangan. Dalam konteks yang lebih luas, id lebih mengarah pada pemenangan hasrat dalam diri daripada mengarah pada etika yang terdapat di masyarakat.

Berkait dengan hal tersebut, Budi Darma, sang pengarang dalam cerpencerpennya, rentang 2016-2020 menunjukkan bahwa judul cerpen yang ditulisnya merupakan representasi dari eksklusi perempuan. Hal itu tampak kuat pada pilihan diksi yang digunakan sebagai judul. Dalam pandangan psikologi dinamik, diksi yang dimunculkan oleh seseorang tidak akan lepas dari hasrat ketidaksadaran individualnya.

Diksi judul cerpen "Suara di Bandara (2018, Kompas), "Lorong Gelap (2018, Kompas), "Bukan Mahasiswa Saya" (2017, Jawa Pos), "Tarom" (2017, Kompas), "Tukang Cukur" (2016, Kompas), "Presiden Jebule" (2016, Kompas), "Darojat dan Istrinya" (2016, Jawa Pos), "Prokol Bambu Martoyo (Jawa Pos, 2020) menunjukkan bahwa pria lebih banyak dimunculkan daripada perempuan. Judul yang menggunakan diksi pria ada dua, yakni 'Tarom', 'Darojat', dan Martoyo, sedangkan diksi untuk perempuan tidak dimunculkan dengan penamaan nama, tetapi hanya penyebutan saja 'istri'. Hal ini menunjukkan eksklusi terhadap perempuan. Dalam konteks psikologis, sang pengarang terkadang tidak sadar memunculkan diksi tersebut sebab didorong oleh eksistensi gender yang melekat pada dirinya. Sebagaimana diketahui bersama bahwa Budi Darma, sang pengarang, adalah pria pengarang. Dengan begitu, secara tidak sadar kekuatan untuk menguatkan gender prianya masih berakar dalam diri. Namun, eksklusi yang dimunculkan dalam pilihan judul tersebut tidak ekstrim sebab diksi yang digunakan di judul hanya menggunakan kata pria tanpa ada embel-embel menguatkan atau menunjukkan sisi keunggulan pria. Begitu juga dengan perempuan, diksi istri juga tidak dimunculkan secara kuat apakah istri yang baik ataukah istri yang buruk.

Fenomena pemunculan laki-laki sebagai judul cerpen merupakan alam ketidaksadaran individual sang pengarang 
yang lebih kuat sisi kelaki-lakiannya. Karena itu, alam bawah sadar sang pengarang menuntun dirinya untuk membuat judul dan memunculkan nama laki-laki. Nama lakilaki yang dimunculkan tersebut bukan tanpa ketidaksengajaan, tetapi lebih mengarah pada alam bawah sadar yang menuntun seseorang untuk melakukan tindakan tertentu. Karena itu, dalam hal ini, sang pengarang bisa saja mengelak bahwa dia sebenarnya tidak berniat untuk menuliskan nama laki-laki dalam judul cerpennya. Namun, sebenarnya dalam konteks psikologis, si pengarang tersebut memang di dorong oleh alam bahwa sadar yang kadang sang pengarang sendiri tidak merasakan dan kadang menyangkal dengan hal tersebut.

Berkait dengan penyangkalan dalam ketidaksadaran yang dilakukan oleh seseorang, Freud (2019) menunjukkan bahwa memang kadang pengarang atau seseorang menyangkal perbuatan ketidaksadarannya sebab dia memang tidak merasa melakukan hal tersebut. Padahal, dia sebagai sang pelaku telah melakukan hal tersebut. Dengan demikian, disangkal atau tidak, alam ketidaksadaran memang sudah melakukan cara kerjanya, yakni berada di alam bawah sadar sehingga si pelaku kadang tidak menyadari jika dia melakukan suatu tindakan/perilaku yang dalam kesadarannya tidak tidak mengenalnya.

Dalam cerpen "Suara dari Bandara", eksklusi perempuan dimunculkan dalam bentuk yang contradictiointerminis, yakni pada satu sisi, sang pengarang sebagai narator memunculkan diksi bahwa sang perempuan adalah sosok yang memiliki kecantikan dan kecekatan. Sosok perempuan direpresentasikan sebagai sosok yang seolah sempurna dan memiliki kesempurnaan. Namun, di sisi lain sang pengarang sebagai narator juga menunjukkan bahwa sosok perempuan adalah perempuan yang suka menghina orang lain. Perempuan yang memiliki kekurangan. Diksi inilah yang memunculkan konstruksi eksklusi terhadap perempuan sebab perempuan digambarkan sebagai orang yang suka menghina orang lain. Gambaran tersebut tampak pada konteks berikut.

"Dia cantik, cekatan, berani, dan suka menghina orang lain (Darma, 2018a)

Berdasarkan kutipan tersebut tampak bahwa eksklusi perempuan berkait dengan perempuan yang melakukan penghinaan. Dalam konteks ini, perempuan memang direpresentasikan sebagai subjek, tetapi subjek tersebut merupakan bentuk subjek yang negatif. Subjek tersebut merupakan eksklusi sebab menggambarkan perempuan dalam bingkai yang jahat (dalam konteks psikologis bisa dikategorikan dalam demonologis). Artinya, perempuan direpresentasikan sebagai sosok yang jahat, meskipun dari luarnya kelihatan baik.

Eksklusi terhadap perempuan yang dinarasikan oleh sang pengarang tersebut menggunakan diksi yang halus sebab eksklusi memunculkan bentuk kelebihan pada sosok perempuan. Sosok perempuan memang digambarkan positif, tetapi pada paparan akhir ditunjukkan dan digambarkan bahwa perempuan itu juga memiliki sisi negatif.

Eksklusi dalam bahasa yang konkretisasikan dengan diksi yang ekstrim muncul dalam bentuk yang menggambarkan kejahatan, kekejaman, penghinaan, pengkhianatan, penipuan, ataupun pencurian. Eksklusi tersebut terkategorikan dalam eksklusi yang kuat dan kerasa. Namun, dalam konteks bahasa yang halus, eksklusi muncul dalam bentuk perundungan, dan pelecehan secara bahasa. Bentuk yang halus tersebut terkategorikan eksklusi yang halus sebab dalam konteks tersebut diksi bahasa. Penggunaan bahasa memang tidak akan lepas dari bentuk eksklusi sebab sang pengarang sebagai sosok kreator tidak akan lepas dari konstruksi pikir kegenderannya.

Dalam hal ini, eksklusi terhadap perempuan dilakukan dengan menggunakan 
bahasa yang halus sehingga seolah-olah tidak mengeksklusi perempuan. Karena itu, diksi yang dimunculkan menggunakan bahasa simbol yang di dalamnya dibungkus secara bagus dan hanya orang-orang yang mampu membongkarnya sehingga bisa memahami hal tersebut. Diksi /suka menghina orang lain/ yang sebelumnya disejajarkan dengan diksi /Dia cantik, cekatan, berani/ yang diungkapkan oleh sang tokoh berkait dengan perempuan yang suka menghina merupakan representasi bahasa halus pengekslusian sebab menunjukkan secara implisit bahwa perempuan tersebut kurang baik secara etika.

\section{Eksklusi Perempuan pada Masa Perang}

Cerpen "Tarom" mengisahkan perempuan masa kini yang dikisahkan ke masa lalu. Sebuah masa perang besar yang di kenal dengan perang dunia I dan perang dunia II. Pada masa inilah, para pria dari ras penjajah dengan segala daya dan dengan segala hasrat libidinalnya melakukan 'penuangan hasrat' pada perempuan.

Pada masa perang tersebut banyak kejadian pemerkosaan, pelecehan seksual, bahkan penculikan pada perempuan. Fakta tersebut menunjukkan bahwa perempuan dalam masa-masa itu menjadi sosok yang sama sekali tidak berdaya dalam menghadapi opresi dari laki-laki. Laki-laki yang menjadi penjajah negara sekaligus menjadi sosok pemerkosa, pembunuh, dan penculik perempuan. Kasus seperti itu jika mengacu pada pandangan Altman (2001) menjadi bagian dari seks global. Seks yang sebenarnya kategori transnasional dan harus diselesaikan oleh masyarakat internasional. Penyelesaian penanganan terhadap kasus penindasan seksual terhadap perempuan tingkat global bukan hal yang mudah sebab itu memerlukan sinergi dari berbagai pihak terutama konteks internasional-kollaboratif.

Salah satu kasus internasional yang berkait dengan pelecehan dan penindasan seksual terhadap perempuan di Indonesia salah satu di antaranya yang terkenal adalah jugun ianfu, budak pada masa penjajahan Jepang. Armiwulan (2014) memberikan gambaran bahwa jugun ianfu merupakan potret kelam perempuan pada masa penjajahan. Perempuan yang masuk dalam jugun ianfu benar-benar diperlakukan tidak manusiawi.

Gertrude menunduk, lalu berkata: Saya tahu siapa dia. Martin Bormann namanya. Darah saya kotor (Darma, 2017)

Tokoh Gertrude dalam kutipan tersebut merupakan tokoh perempuan sekarang yang sebenarnya merasa tereksklusi oleh narasi masa lalu. Narasi zaman penjajahan yang banyak menenggelamkan dan merenggut cita-cita luhur perempuan dalam menunjukkan eksistensinya sebagai seorang perempuan. Mereka terbatasi, terkungkung, dan tergarisi oleh apa yang disebut dengan perbudakan. Lebih parah lagi, perbudakan perempuan. Sebuah perbudakan yang radikal seradikalradikalnya.

Gertrude merupakan anak dari perempuan yang hidup pada masa penjajahan. Karena itu, sebagai perempuan dia merasa tidak nyaman dengan masa lalunya yang bisa jadi dianggap kelam oleh sebagaian besar orang. Dalam hal ini kekelaman tersebut bukan karena disebabkan oleh dirinya sendiri, melainkan karena keadaan dan situasi politik waktu itu. Dia sebagai sosok perempuan merupakan individu yang tidak berdaya pada masa itu. Karena itu, dia menjadi perempuan yang menjadi budak nafsu laki-laki penjajah. Dalam konteks psikologis tokoh Gretrude, sebagai sosok perempuan yang mengalami masa-masa pahit --perbudakan perempuan tersebut-merasakan bahwa hal tersebut adalah kekejaman.

Apa yang dirasakan oleh Gertrude pada masa kini merupakan memori kolektif masa lalu yang sangat menyakitkan. Hal itu mengakibatkan dirinya juga tereksklusi oleh memori masa lalu tersebut. Padahal, dia tidak bersalah sama sekali dan itu juga 
bukan kesalahan dari ibunya pula. Namun, kesalahan dari pria-pria libidis yang menyalurkan hasrat libidinalnya pada perempuan-perempuan yang tak punya kuasa untuk menolak dan melawan. Memori kolektif yang mengakitkan tersebut akan menjadikan trauma yang mendalam bagi diri kaum perempuan yang mengalami kekerasan seksual tersebut.

Ketidakadilan terhadap perempuan dalam hal seksual memang sangat kuat terjadi pada masa lalu, terutama tatkala gelombang feminisme belum menguat. Hal itu ditunjukkan oleh Saadawi (2015) bahwa perempuan pada masa lalu banyak dikalahkan, ditindas, dan disakiti oleh kaum laki-laki. Dalam konteks ini, laki-laki menjadi sosok penguasa yang memiliki kekuasaan mahabesar sehingga bisa melakukan apa saja kepada perempuan, baik dalam segi perempuan di keluarga ataupun perempuan di tempat kerja. Perempuan dikalahkan oleh budaya patriarkhi yang memang sudah ditanamkan sejak dahulu oleh kaum laki-laki. Dengan begitu, perempuan menjadi tidak berdaya sebab mereka kalah dari segi budaya yang memang didominasi oleh laki-laki.

Dalam konteks penjajahan, eksklusi perempuan tidak hanya pada konteks psikologis saja, melainkan konteks fisik. Perempuan sebagai manusia yang merdeka secara lahiriah dan batiniah ternyata semuanya direnggut oleh penjajah. Inilah yang disebut dengan eksklusi terhadap perempuan, baik secara lahir dan batin. Perempuan benar-benar tidak diberi hak untuk menyuarakan dirinya sendiri sebagai manusia merdeka. Hal ini merupakan dampak dari penjajahan yang tidak hanya menjajah negara dan mengambil sumber daya alam yang terdapat di dalamnya, tetapi juga mengambil hak-hak perempuan.

Perempuan sebagai sosok yang teropresi memang tidak mampu melakukan perlawanan terhadap penjajah yang demikian hebatnya memasung dan mengebiri kebebasan. Itulah yang disebut mati semati-matinya untuk kebebasan. Eksklusi perempuan di sini eksklusi yang radikal sebab mengakar sampai ke akarakarnya. Tidak ada kebebasan sama sekali di dalamnya. Bahkan, kebebasan untuk memerdekakan diri sendiri sebab mereka dijadikan budak libidinal oleh penjajah.

Itulah gambaran perempuan masa lalu yang tak mampu membebaskan dirinya sendiri dari belenggu libidis laki-laki. Imbasnya, di masa kini, belenggu tersebut masih ada dan hal tersebut dianggap sebagai noda yang takkan hilang oleh perempuan. Dalam hal ini, salah harga diri perempuan Asia (timur) terletak pada masalah kegadisannnya. Ketika dia merasa tidak gadis lagi gara-gara diperkosa, dia merasa tidak nyaman dengan dirinya sendiri.

\section{Esklusi Pelabelan Perempuan}

Pelabelan merupakan bagian dari eksklusi terhadap perempuan berkait dengan pemberian stigma yang negatif. Hal ini muncul dalam bentuk pengataan yang meminggirkan, menyudutkan, menjelekkan, dan mengobjekkan perempuan. Dalam cerpen "Darojat dan Istrinya" sang pengarang menunjukkan representasi eksklusi yang berkait dengan pelabelan terhadap perempuan. Gambaran tersebut tampak pada kutipan berikut.

Darmono berbohong lagi: "Wahai perempuan jalang, seluruh dunia tahu dokter bejat ini punya banyak perempuan simpanan (Darma, 2016)

Penggunaan diksi /perempuan jalang/, /perempuan simpanan/ menunjukkan eksklusi perempuan melalui bahasa. Perempuan dieksklusikan sebagai sosok yang jalang dan simpanan. Dalam bahasa keseharian, perempuan jalang, perempuan simpanan, merupakan bahasa yang menyudutkan, meminggirkan, menghinakan, dan menjelekkan perempuan. Perempuan yang mendapatkan julukan seperti itu tentu merasa tidak senang dan tidak nyaman sebab dia dieksklusikan sebagai orang yang 
terkategorikan 'jalang' dan 'simpanan'. Pengeksklusian tersebut disebabkan adanya pertarungan bahasa antara bahasa yang digunakan oleh pria dan perempuan. Dalam cerpen "Darojat dan Istrinya" penggunakan diksi perempuan jalang dan perempuan simpanan dimunculkan oleh tokoh pria. Hal ini menunjukkan bahwa yang mengeksklusikan perempuan adalah sosok pria.

Dalam perspektif wacana kritis, bahasa juga mampu mengeksklusikan seseorang sebab bahasa merupakan alat 'permainan' yang mampu meminggirkan dan menguatkan orang. Karena itu, dalam pandangan Dijk (2006, 2008, 2014), di dalam bahasa terepresentasikan ketidakadilan, keopresian, dan kekuasaan. Bahasa memiliki simbol-simbol yang tersembunyi dalam diksi-diksi harus diinterpretasikan secara heuristik dan hermeneutik agar bisa ditemukenali makna yang terkandung di dalamnya. Penginterpretasian tersebut memngutuhkan penggalian pada tahapan permukaan dan tahapan inti bahasa. Karena itu, teks, koteks, dan konteks dalam pandangan Dijk (2006) sangat dibutuhkan untuk memahami secara komprehensif sebuah bahasa. Dalam "Tamu", sosok perempuan digambarkan secara jelas dengan menggunakan diksi 'jahat'. Gambaran tersebut tampak pada kutipan berikut.

Tapi sayang, katanya, menantunya yaitu istri Suroto, benar-benar jahat (Darma, 2019)

Penggunaan diksi /jahat/ tersebut menunjukkan secara eksplisit pelabelan terhadap diri perempuan. Dalam konteks ini, perempuan sebagai sosok menantu digambarkan jahat sebab dia (si menantu) menyuruh si mertua minggat dari rumah. Padahal itu, adalah rumahnya dia sendiri. Tidak hanya itu, si menantu (perempuan) tidak berkenan memberikan/membuatkan kopi untuknya. Padahal, jika dia tidak diberi 126 kopi, dia bisa mati. Hal ini menunjukkan secara kuat bahwa perempuan dilabelkan sebagai sosok jahat, sosok tidak memiliki etika pada mertua. Pada sisi lain, si menantu (perempuan) digambarkan sebagai sosok gembel. Gambaran tersebut tampak pada kutipan berikut.

Istri Suroto, yaitu menantu saya berasal dari keluarga jembel, mirip-mirip pengemis (Darma, 2019).

Berdasarkan kutipan tersebut tampak secara eksplisit bahwa diksi /jembel/ yang disematkan pada menantu perempuan merupakan pelabelan yang merugikan bagi kaum perempuan. Hal tersebut disebabkan si perempuan disetarakan dengan jembel dan pengemis. Padahal, si mertua sebagai representasi dari laki-laki tidak menunjukkan asal-muasal dirinya. Ini menunjukkan labelisasi perempuan dengan cara melabeli perempuan sebagai sosok jembel, sedangkan laki-laki tidak mendapatkan pelabelan. Dalam hal ini, pelabelan yang dimunculkan untuk perempuan merupakan representasi kuasa laki-laki dalam konteks bahasa.

Dalam "Prokol Bambu Martoyo" sosok perempuan digambarkan sebagai pembunuh. Perempuan yang bernama Bik Rimang, dalam novel tersebut membunuh suaminya sendiri yang bernama Jemprot yang telah bermain dengan seorang pelacu. Amarah Bik Rimang memuncak sebab suaminya melakukan hubungan seksual dengan pelacur di rumah mereka sendiri. Dalam cerpen tersebut sang pengarang menarasikan bahwa Bik Rimang membunuh sang suami.

kepala Jemprot ditebas oleh Bik Rimang menjadi dua bagian... (Darma, 2020)

Berdasarkan kutipan tersebut tokoh Jemprot mati seketika tatkala dia dicelurit oleh Bik Rimang. Dalam cerpen tersebut 
digambarkan bahwa otak suaminya terburai ke mana-mana. Penggambaran ini menunjukkan bahwa eksklusi dimunculkan untuk perempuan dalam kaitannya dengan pembunuhan. Tokoh Bik Rimang, seorang perempuan yang bersuami, ternyata tega membunuh suaminya sendiri dengan menggunakan celurit. Perempuan dalam konteks ini dilabeli sebagai pembunuh. Dia, Bik Rimang adalah pembunuh suaminya sendiri. Diksi 'pembunuh' menunjukkan bahwa sosok orang yang sudah dilabeli pembunuh adalah kategori jahat, berbahaya, dan mematikan. Karena itu, orang-orang yang dilabeli pembunuh harus dijauhi.

\section{PENUTUP}

Berdasarkan hasil pemaparan di muka disimpulkan sebagai berikut. Dalam perspektif psikologi gender, cerpen karya Budi Darma memunculkan eksklusi perempuan yang terepresentasikan melalui tiga segmentasi. Pertama, eksklusi perempuan muncul melalui penggunaan judul yang lebih banyak menonjolkan, menguatkan, dan memajankan diksi kepriaan. Adapun judul yang menggunakan diksi keperempuanan tidak dimunculkan secara kuat. Kedua, eksklusi perempuan masa perang. Pada masa lalu, perempuan direpresentasikan sebagai sosok yang diopresi dan diinjak-injak oleh pria. Mereka dijadikan budak libinal oleh pria. Trauma tersebut sampai sekarang tidak akan hilang dalam diri perempuan. Ketiga, pelabelan perempuan. Dalam konteks ini, perempuan dilabelkan sebagai sosok yang jalang dan simpanan. Pelabelan tersebut meminggirkan, menyudutkan, dan menjelekkan martabat perempuan.

Dalam konteks yang universal, sastra menyuarakan kebenaran yang berkait dengan eksklusi perempuan. Karena itu, dalam berbagai sastra di berbagai negera, terdapat eksklusi perempuan yang digambarkan oleh pengarang dengan menggunakan estetika yang berbeda.
Namun, dalam hal ini pengarang (baik lakilaki pengarang ataupun perempuan pengarang) sama-sama menyuarakan kebenaran mengenai eksklusi perempuan.

Rekomendasi/saran untuk peneliti selanjutnya, penelitian ini masih terbatas pada karya sastra yang ditulis oleh Budi Darma. Karena itu, peneliti bisa menggali lebih dalam eksklusi gender dalam sastra Indonesia yang ditulis oleh berbagai pengarang. Dengan demikian, bisa ditemukan eksklusi gender secara komprehensif dalam sastra Indonesia.

\section{DAFTAR PUSTAKA}

Ahmadi, A. (2021) The Traces of Oppression and Trauma to Ethnic Minorities in Indonesia Who Experienced Rape on the 12 May 1998 Tragedy: A Review of Literature. Journal of Ethnic and Cultural Studies, 8(2),126-144. http://dx.doi.org/10.29333/ejecs/744

Ahmadi, A. (2014). Perempuan Agresif dan Opresif dalam Antologi Cerpen Kompas 2012: Tinjauan Psikologi Gender. Jurnal Lentera, 10 (1): 6574.

Ahmadi, A. (2015). Perempuan dalam Sastra Lisan di Pulau Raas: Kajian Gender. Jurnal Bahasa dan Seni. 43 (1): $57-65$.

Ahmadi, A. (2015). Psikologi Sastra. Surabaya: Unesapress.

Ahmadi, A. (2017). Maskulinitas dalam Sastra Tiongkok. Manusia, Kebudayaan dan Politik., 32 (2):103-113.

Ahmadi, A. (2019a). Metode Penelitian Sastra. Gresik: Graniti.

Ahmadi, A. (2019b). The Use of Sinta (Science and Technology Index) Database to Map the Development Of Literature Study In Indonesia. International Journal of Mechanical Engineering and Technology (IJMET), 10 (2):918-923 
Ahmadi, A. (2019c). Narasi Kematian Dalam Fiksi Indonesia Modern: Perspektif Psikologi Kematian. Jurnal Bahasa Lingua Scientia, 11(1), 27-40. http://doi.org/10.21274/1s.2019.11.1. 27-40.

Ahmadi, A. Ghazali, A.S., Dermawan, T., Maryaeni. (2019). Ecopsychology and Psychology of Literature: Concretization of Human Biophilia That Loves the Environment in Two Indonesian Novels. The International Journal of Literary Humanities, 17(1): 47-

60.http://doi.org/10.18848/23277912/CGP/v17i01/47-59

Altman, D. (2001). Global Sex: Politisasi Seksual, Komersialisasi Tubuh, dan Hubungan Internasional. Terjemahan Dede Nurdin. Jakarta: Qalam.

Armiwulan, H. (2014). Jugun Ianfu Sebagai Potret Kelam Perempuan Korban Kejahatan Perang (1). Aina: Citra Perempuan Indonesia, 4, 15-18.

Briones, L. (2019). Empowering Migrant Women. Burlington: Ashgate.

Corse, S. M., \& Westervelt, S. D. (2002). Gender and Literary Valorization: The Awakening of a Canonical Novel. Sociological

Perspectives, 45(2), 139 161. https://doi.org/10.1525/sop.2002. 45.2.139

Conger, V. (2009). The Widows' Might: Widowhood and Gender in Early British America. New York: New York University Press.

Creswell, J. W., \& Creswell, J. D. (2019). Research Design: Qualitative, Quantitative, and Mixed Methods Approaches. Thousand Oaks, California : SAGE Publications

Darma, B. (2002). Kritikus Adinan dan cerita lainnya. Jogjakarta, Indonesia: Bentang Budaya.
Darma, B. (2009). Olenka. Jakarta: Balai Pustaka.

Darma, B. (1988). Rafilus. Jakarta: Balai Pustaka.

Budi, D. (1996). Ny. Talis: Kisah mengenai Madras. Jakarta: Gramedia Widiasarana Indonesia.

Darma, B. (2016a). Darojat dan Istrinya. Jawa Pos, 17 Juli.

Darma, B. (2016b). Tukang Cukur. Kompas, 11 September.

Darma, B. (2016c). Presiden Jebule. Kompas, 5 Juni.

Darma, B. (2017a). Tarom. Kompas, 20 Agustus.

Darma, B. (2017b). Bukan Mahasiswa Saya. Jawa Pos, 20 Agustus

Darma, B. (2018a). Suara di Bandara. Kompas, 2 Desember.

Darma, B. (2018b). Lorong Gelap. Kompas, 24 Juni.

Darma, B. (2019). Tamu. Kompas, 29 Agustus.

Darma, B. (2020). Prokol Bambu Martoyo. Jawa Pos, 30 Agustus.

Dijk TA. (2006). Discourse and manipulation. Journal Discourse and Society. 17(3):359-383. doi.org/10.1177/0957926506060250

Dijk TA. (2008). Discourse and context: A sociocognitive approach. New York: Cambridge University Press.

Dijk TA. (2014). Discourse-CognitionSociety. InChristopher Hart \& Piotr Cap (Eds). Contemporary Studies in Critical Discourse Analysis. (pp. 121-146).London: Bloomsbury.

Freud, S. (1920). A General Introduction to Psychoanalysis. New York: Horace Liveright.

Freud, S. (2019). The Interpretation of Dreams. Muncen, German: Muncen Neobook.

Gergen, M. M. (2010). Qualitative Inquiry in Gender Studies. InJoan C. Chrisler \& Donald R. McCreary (Eds), Handbook of Gender Research in 
Eksklusi Perempuan, Sastra, dan Psikologi Gender .... (Anas Ahmadi)

Psychology, pp.103-132.New York: Springer.

Gregory, R. F. (2003). Women and Workplace Discrimination: Overcoming Barriers to Gender Equality.New Brunswick, N.J.: Rutgers University Press

Helgeson, V. J. (2012). The Psychology of Gender. Boston: Pearson.

Janssen, A., \& Murachver, T. (2005). Readers' Perceptions of Author Gender and Literary Genre. Journal of Language and Social Psychology, 24(2), 207219. https://doi.org/10.1177/0261927X 05275745

Jacobsen, J. P. (2011). Gender Inequality A Key Global Challenge: Reducing Losses due to Gender Inequality. Midlle Town: Copenhagen Consensus on Human Challenges.

Jeydel, A. (2004). Political Women: The Women's Movement, Political Institutions, the Battle for Women's Suffrage and the ERA. London: Routledge.

Lanza, J. M. (2007). From Wives to Widows In Early Modern Paris. Burlington: Ashgate.

Orabueze, F. O. (2016). Society, women and literature in Africa. Port Harcourt, Nigeria: $M$ \& $J$ Grand Orbit Communications Ltd.

Page, E. R. (2003). Feminist narratology? Literary and linguistic perspectives on gender and narrativity. Language and
Literature, 12(1),

56. https://doi.org/10.1177/096394700 301200103

Reeder, L. (2003). Widows in White: Migration and the Transformation of Rural Women, Sicily, 1880-1928 (Studies in Gender and History). Toronto: University of Toronto Press.

Ridgeway, C. L. (2011). Framed by Gender: How Gender Inequality Persists in the Modern World. Oxford: Oxford University Press

Saadawi, N. (2021). The Hidden Face of Eve: Women in the Arab World. London: Zed Book.

Saadawi, N. (2015). Women at Point Zero. London: Zed Book.

Sakariyau, R.\& Zakuan, U.A.A. (2017). Gender Inequality and the Challenges of Human Development: The Nigerian and Malaysian Experience. $J G D, 13$ (1), 65-82.

Siswanto, W. (2005). Budi Darma: Karya dan dunianya. Jakarta: Gramedia Widiasarana Indonesia.

Suman (2018). Gendered Migrations and Literary Narratives: Writing Communities in South Asian Diaspora. Millennial Asia,9(1), 93108. https://doi.org/10.1177/09763996 17753755

Warren, J. W. (2005). Women, Money, and the Law: Nineteenth-Century Fiction, Gender, and Courts. Iowa City : University of Iowa Press 